\title{
Epstein-Barr Virus-Related Atypical Lymphoproliferative Disorders in Waldeyer's Ring: A Clinicopathological Study of 9 Cases
}

\author{
Masaru Kojima $^{a}$ Naoya Nakamura ${ }^{b}$ Hideaki Itoh ${ }^{c}$ Ken Shimizu ${ }^{d}$ \\ Kazuhiko Shimizu ${ }^{e}$ Hazuki Matsuda ${ }^{a}$ Yoshio Tamaki $^{f}$ Nobuhide Masawa $^{a}$ \\ Shigeo Nakamurag \\ ${ }^{a}$ Department of Anatomic and Diagnostic Pathology, Dokkyo University School of Medicine, Mibu, ${ }^{b}$ Department of \\ Pathology, Tokai University School of Medicine, Isehara, 'Department of Pathology and Clinical Laboratories, \\ Maebashi Red Cross Hospital, Maebashi, ' Department of Pathology, Saitama Social Insurance Hospital, Saitama, \\ e Department of Pathology and Clinical Laboratories, Ashikaga Red Cross Hospital, Ashikaga, ${ }^{\text {'Department of }}$ \\ Radiology, Gunma Cancer Center Hospital, Ohta, and ${ }^{9}$ Department of Pathology and Clinical Laboratories, \\ Nagoya University School of Medicine, Nagoya, Japan
}

\section{Key Words}

Epstein-Barr virus • Waldeyer's ring $\cdot$ Lymphoproliferative disorders

\begin{abstract}
Background and Study Aim: Because of the small biopsy specimens in the Waldeyer's ring (WR) the differential diagnosis between Epstein-Barr virus (EBV)-associated lymphoproliferative disorder (LPD) and malignant lymphoma is occasionally difficult. We report here clinicopathological, immunohistochemical and genotypic findings of 9 cases of EBV-associated LPDs in WR. Patients and Methods: Using formalin-fixed paraffin-embedded sections, histological analyses, immunohistochemistry, in situ hybridization and polymerase chain reaction were performed. Results: Clinically, all 9 cases showed more than one atypical clinical finding of infectious mononucleosis including absence of systemic symptoms, absence of atypical lymphocytosis and age over 30 years. Histologically, 3 types were delineated: (1) Hodgkin lymphoma-like ( $n=1),(2)$ T cell/histiocyte-rich large $B$ cell lymphoma-like ( $n=4)$, and (3) marginal zone $B$ cell lymphoma of mucosa-associated lymphoid tissue
\end{abstract}

(MALT)-like $(n=4)$. The in situ hybridization study demonstrated EBV-encoded small RNA (EBER)+ cells in all 9 lesions. The immunohistochemical and flow cytometry study demonstrated the reactive nature of the $B$ cells in all 9 lesions. However, 3 of our 7 cases examined demonstrated immunoglobulin heavy chain gene rearrangement on PCR study. There was no development of B cell lymphoma in any of the 3 lesions demonstrating $\mathrm{lgH}$ rearrangement. Conclusion: EBV-associated LPDs of the WR showed marked histological diversity. Among these, a MALT-like pattern was frequently seen. Marginal zone B cell lymphoma frequently affects WR. We emphasized that EBV-associated LPD should be added to the differential diagnosis of primary tonsillar MALT-type lymphoma.

Copyright $\odot 2010$ S. Karger AG, Basel

\section{Introduction}

Infectious mononucleosis (IM) is an acute lymphoproliferative disorder (LPD) that typically occurs in young patients and is usually caused by Epstein-Barr virus (EBV) $[1,2]$. The diagnosis of IM is usually based on

\section{KARGER}

Fax +41613061234 E-Mail karger@karger.ch www.karger.com

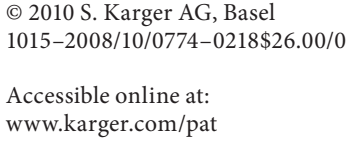

Dr. Masaru Kojima

Anatomic and Diagnostic Pathology, Dokkyo University School of Medicine 321-0293 Mibu (Japan)

Tel. +81 28286 1111, ext. 2178, Fax +81 282865171

E-Mail k-masaru@dokkyomed.ac.jp 
Table 1. Summary of clinical findings

\begin{tabular}{|c|c|c|c|c|c|c|c|}
\hline No. & $\begin{array}{l}\text { Age/ } \\
\text { gender }\end{array}$ & Site of lesion & Symptoms & Clinical diagnosis & $\begin{array}{l}\text { Atypical } \\
\text { Ly in PB }\end{array}$ & EBV findings & Outcome \\
\hline 1 & $14 / \mathrm{M}$ & Epipharynx and Bil. neck LN & Sore throat & Abscess & - & VCA-IgM $<10$ & $8 \mathrm{~m}$ alive $(-)$ \\
\hline 2 & $20 / \mathrm{M}$ & Epipharynx and Bil. neck LN & Fever & Carcinoma & NA & NA & $8 \mathrm{~m}$ alive $(-)$ \\
\hline 3 & $25 / \mathrm{M}$ & Epipharynx & - & Tumor & - & $\mathrm{EA}+, \mathrm{VCA}-\operatorname{IgM} \times 10$ & $12 \mathrm{~m}$ alive $(-)$ \\
\hline $4^{\mathrm{a}}$ & $36 / \mathrm{M}$ & Lt. tonsil and Lt. neck LN & - & Malignant lymphoma & $9 \%$ & $\mathrm{EA}+, \mathrm{VCA}-\mathrm{IgM}+$ & $24 \mathrm{~m}$ alive $(-)$ \\
\hline 5 & $56 / \mathrm{F}$ & Rt. tonsil & - & Tumor & $\mathrm{NE}$ & NE & $60 \mathrm{~m}$ alive $(-)$ \\
\hline $6^{\mathrm{b}}$ & $57 / \mathrm{F}$ & Lt. tonsil and neck LN & Sore throat & Malignant lymphoma & $7 \%$ & VCA-IgG $\times 320$ & $61 \mathrm{~m}$ alive $(-)$ \\
\hline 7 & $68 / \mathrm{F}$ & Epipharynx and Lt. neck LN & Sore throat & Malignant lymphoma & - & VCA-IgG $\times 640$ & $\begin{array}{l}14 \text { m Rt. neck LN relapse, } \\
30 \text { m alive (-) }\end{array}$ \\
\hline 8 & $70 / \mathrm{M}$ & Rt. tonsil and neck LN & Sore throat & Malignant lymphoma & - & VCA-IgG $=7.7 \mathrm{~g} / \mathrm{ml}$ & $48 \mathrm{~m}$ alive $(-)$ \\
\hline 9 & $88 / \mathrm{F}$ & Rt. tonsilla & Sore throat & Tumor & - & NA & $12 \mathrm{~m}$ died $(-)$ \\
\hline
\end{tabular}

Ly in PB = Lymphocytes in peripheral blood; VCA = EBV capsid antigens; $\mathrm{m}=$ months; Bil. = bilateral; $\mathrm{LN}=$ lymph node; $\mathrm{NA}=$ not available; Lt. = left; Rt. = right; $\mathrm{NE}=$ not examined; $(-)=$ without disease.

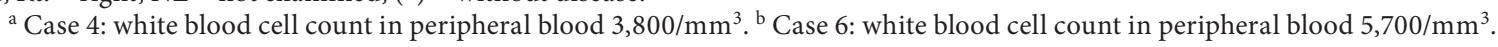

clinical and serological findings [2]. However, a lymphoid tissue biopsy may be performed when malignant lymphoma is a clinical consideration in patients demonstrating atypical clinical features [1,3-7]. Atypical features include age over 30 years, generalized lymphadenopathy, or isolated lymphadenopathy in an unusual site, tonsillar mass, negative heterophil antibody titer or absence of atypical lymphocytosis in peripheral blood [3-7].

In such instances, diagnostic problems for surgical pathologists may arise because the histopathological features of IM may simulate those of either Hodgkin lymphoma (HL) or non-HL $[1,3,8,9]$. Moreover, because of the small biopsy specimens in the Waldeyer's ring (WR), differential diagnosis between EBV-associated LPD and malignant lymphoma may occasionally be difficult $[6,8]$. Recently, we have reported 2 cases of tonsillar lesion of IM resembling marginal zone B cell lymphoma (MZBCL) of mucosa-associated lymphoid tissue (MALT) type [10]. To further clarify the clinicopathological findings of tonsillar lesions of IM, we reviewed 9 such cases.

\section{Patients and Methods}

Nine cases were collected from a series treated by one of the authors (M.K.) between 1999 and June 2009. The medical records of 8 cases were extensively reviewed. Five cases (No. 4-6, 8 and 9) had been reported previously $[7,10]$.

Specimens were fixed in formalin, routinely processed and embedded in paraffin. For light-microscopic examination, the sections were stained with hematoxylin-eosin (HE).

A basic immunohistochemical panel including antibodies against human immunoglobulin light chain ( $\kappa$ and $\lambda$; Novocastra, New Castle, UK or Dako A/S, Glostrup, Denmark), 4C7 (CD5;
Novocastra), L26 (CD20; Dako), Ber-H2 (CD30; Dako), and DFT1 (CD43; Dako or Novocastra) had been used in all 9 cases.

When additional slides and/or paraffin blocks were available, the immunohistochemical analysis was expanded to include antibodies 1F6 (CD4; Novocastra), 4B11 (CD8; Novocastra), C3D-1 (CD15; Dako), cocktail of 2G9 (CD21; Novocastra) and RLB25 (CD35; Novocastra), 1 B12 (CD23; Novocastra), JCB117 (CD79a; Dako), P1F6 (bcl-6; Novocastra) and E29 (EMA; Dako). Immunohistochemical studies were performed using the antigen retrieval method with the avidin-biotin-peroxidase method or Ventana-automated (BenchMark ${ }^{\mathrm{TM}}$ ) stainer according to the manufacturer's instructions.

In situ hybridization with EBV-encoded small RNA (EBER) oligonucleotides was performed to test for the presence of EBV small RNA in formalin-fixed paraffin-embedded sections using a Ventana-automated (BenchMark) stainer or using a hybridization kit (Dako).

DNA was extracted from paraffin-embedded sections. The variable region (CDR2 and FW3) and the VDJ region (CDR3) of the immunoglobulin heavy chain $(\mathrm{IgH})$ gene were amplified by seminested PCR, using primers of FR2B, LJH and VLJH, according to a previously described method [11]. Primers were as follows: 5'-CCGG(A/G)AA(A/G)(A/G)GTCTGGAGTGG-3' as upstream consensus $V$ region primer(FR2B); 5'-TGAGGAGACGGTGACC$3^{\prime}$ as a consensus J region primer (LJH), and $5^{\prime}$-GTGACCAGGGT [A/C/G/T] CCTTGGCCCCAG-3' as a consensus J region primer (VLJH). PCR products were estimated to be about 200-300 bp in length.

\section{Results}

\section{Clinical Findings}

The main clinical findings are shown in table 1 .

The patients including 5 men and 4 women ranged in age from 14 to 88 years with a median age of 56 years. 
'B' symptoms such as fever were recorded in only 1 case (No. 2). Cervical lymph node swelling was recorded in 6 cases (No. 1, 2, 4, 6-8). Small numbers of atypical lymphocytes were found in 2 cases (No. 4 and 6). Hepatosplenomegaly was recorded in 1 case (No. 7) with chronic hepatitis virus type B infection. However, there was no atypical lymphocytosis $(>10 \%)$ in peripheral blood from any of the 9 patients. Mild impairment of the liver function was demonstrated by laboratory tests in 2 patients (No. 3 and 4). Serological evidence of current or recent primary EBV infection in an initial serum specimen was established by the presence of high titers of VCA-specific IgG and antibodies in cases 6 and 7 $(>\times 320)$ and in case $8(7.7 \mathrm{~g} / \mathrm{ml})$ [2]. Positivity for early antigen was detected in cases 3 and 4 . There were no abnormal serological findings for EBV in case 1 . In the remaining 2 cases (No. 2 and 9), serological examinations for EBV were not performed. Information from flow cytometry was available in 3 cases (No. 6-8) that showed a polyclonal B cell population. Positive autoantibodies (direct Coombs' test and rheumatoid factor) were recorded in 1 case (No. 7). Clinically, IM was not suspected in any of the 9 cases. Malignant lymphoma was suspected in 4 cases (No. 4, 6-8), tonsillar tumor in 3 cases (No. 3, 5 and 9), carcinoma in 1 (No. 2) and tonsillar abscess in 1 (No. 1).

Follow-up information was available in all 9 patients for periods ranging from 8 to 61 months (mean 29 months, median 24 months). One female patient (No. 7) was tentatively diagnosed as having diffuse large B cell lymphoma and was given CHOP (cyclophosphamide, doxorubicin, vincristine, prednisolone) therapy. Fourteen months after biopsy, bilateral neck and intra-abdominal lymphadenopathy was observed. She was diagnosed as having lymph node involvement of lymphoma and received CHOP therapy again. One patient (No. 9) died of heart failure after 12 months, while the remaining 8 cases were alive at the last follow-up.

\section{Histological and Immunohistochemical Findings}

All 9 lesions were characterized by obvious expansion of the interfollicular area and effacement of the follicles indicating atypical lymphoid proliferation. The lymphoid follicles had hyperplastic germinal centers with illdefined borders in 5 cases (No. 3-6 and 8), although atrophic germinal centers were common in the remaining 2 cases (No. 7 and 9). There were no lymphoid follicles in two lesions (No. 1 and 2).

Three histological subtypes were delineated.
HL-Like ( $=1$; Case 1$)$

The lesion contained numerous large lymphoid cells including mononuclear Hodgkin $(\mathrm{H})$ cells with a few multinucleated Reed-Sternberg (RS)-like cells admixed with an inflammatory background (fig. 1a).

Immunohistochemical study demonstrated that large lymphoid cells including $\mathrm{H}$ cells and RS-like cells were CD20+ (fig. 1b), CD5-, CD15-. A portion of the large lymphoid cells including $\mathrm{H}$ cells and RS-like cells were CD30+. Immunohistochemical studies of light chain determinants for large lymphoid cells demonstrated a polyclonal pattern (fig. 1c, d).

T Cell/Histiocyte-Rich Large B Cell Lymphoma-Like ( $\mathrm{n}=4$; Cases 2, 3, 5 and 7)

These lesions are comprised of scattered single large transformed lymphocytes embedded in a background of small to medium-sized lymphocytes and histiocytes with or without epithelioid cell features (fig. 1e). The large lymphoid cells are usually dispersed and do not form large aggregates.

The immunohistochemical study demonstrated that the majority of large lymphoid cells were CD20/79a+ (fig. 1f), whereas a minority of them were CD5+ (fig. 1g). A portion of the large $\mathrm{B}$ cells were $\mathrm{CD} 30+$. The majority of small to medium-sized lymphocytes were CD5+. There was a predominance of CD8- over CD4+ T cells in 2 cases (No. 3 and 5), whereas there was an almost equal number of CD8- and CD4+ T cells in the remaining 2 cases (No. 2 and 7). There were no CD43 and/or bcl-6+ large B cells in any of the lesions.

MZBCL of MALT Type-Like ( $\mathrm{n}=4$; Cases 4, 6 ,

8 and 9)

The lymphoid follicles were surrounded by sheet-like proliferation of polymorphous infiltration showing a marginal zone distribution pattern (fig. 2a). Three lesions (No. 4, 8 and 9) contained numerous mature plasma cells, plasmacytoid cells and immature plasma cells with occasional immunoblasts as well as small to medium-sized lymphocytes (fig. 2b). Histiocytes with or without epithelioid cell features were seen in all 4 lesions. These epithelioid cells occasionally formed small clusters in 2 cases (No. 4 and 8). A portion of immunoblasts with large vesicular nuclei and prominent nucleoli resembled $\mathrm{H}$ cells in 2 cases (No. 8 and 9). However, there were no RS-like cells in any of the 4 lesions. The small lymphoid cells usually had regular round nuclei, whereas medium-sized cells occasionally showed nuclear irregularities and a moderate amount of clear cyto- 

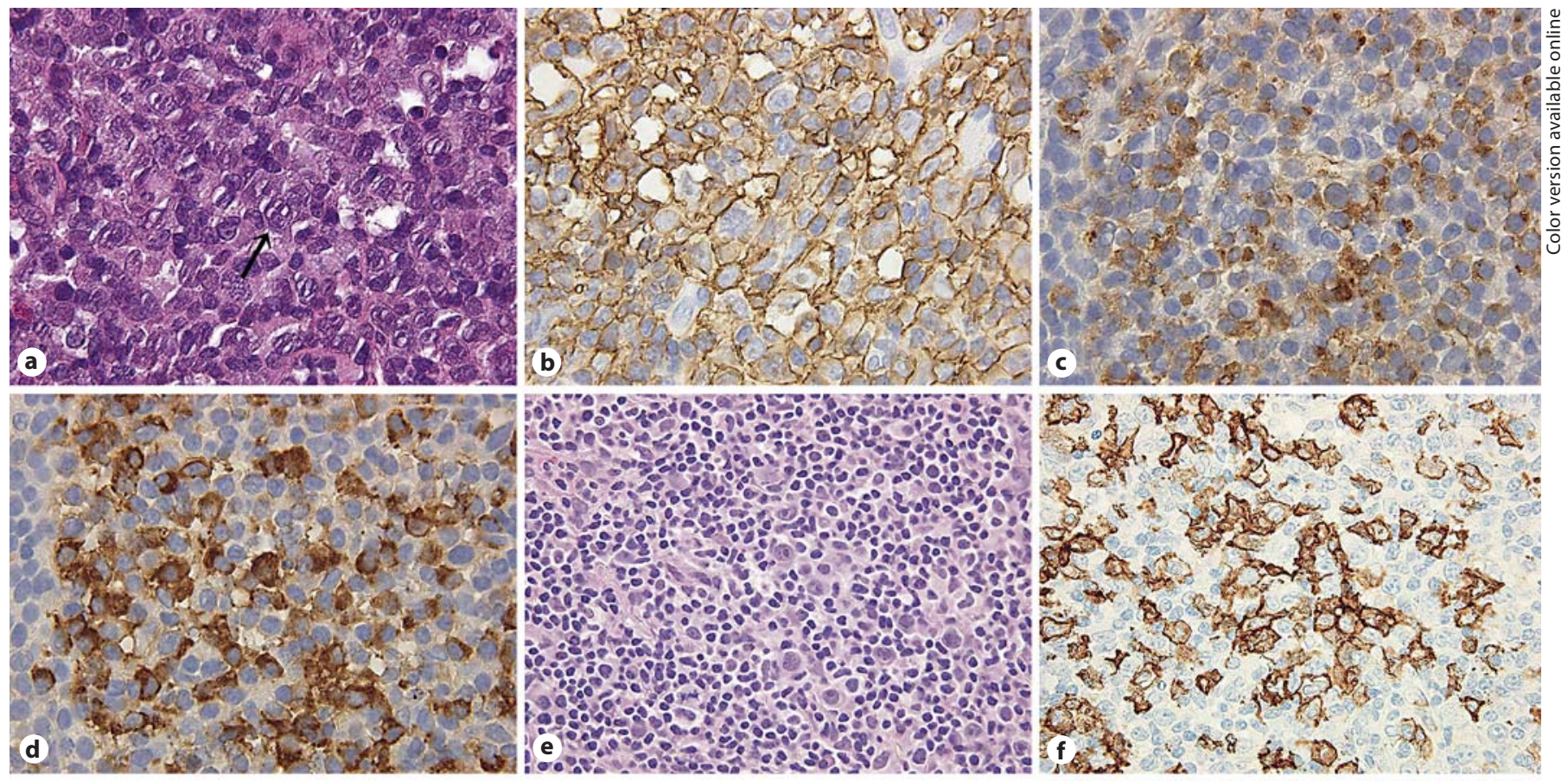

Fig. 1. a On high-power field, the lesion demonstrated numerous large lymphoid cells including mononuclear $\mathrm{H}$ cells with a few multinucleated RS-like cells (arrow) admixed with an inflammatory background (case 1 ). HE. $\times 150$. b Immunohistochemical study demonstrated that large lymphoid cells including $\mathrm{H}$ cells and RS-like cells were CD20+ (case 1). HE. $\times 100 . \kappa(\mathbf{c})$ - and $\lambda(\mathbf{d})$-light chain immunostain demonstrated the polytypic nature of large lymphoid cells (case 1 ). HE. $\times 100$. e On highpower field, the lesion contained scattered large transformed lymphocytes embedded in a background of small lymphocytes and histiocytes with or without epithelioid cell features (case 3). HE. $\times 100$. Immunohistochemical study demonstrated that the majority of large lymphoid cells were CD20 (f), whereas a minority of these cells were CD5+ (g) (case 5). HE. $\times 100$.

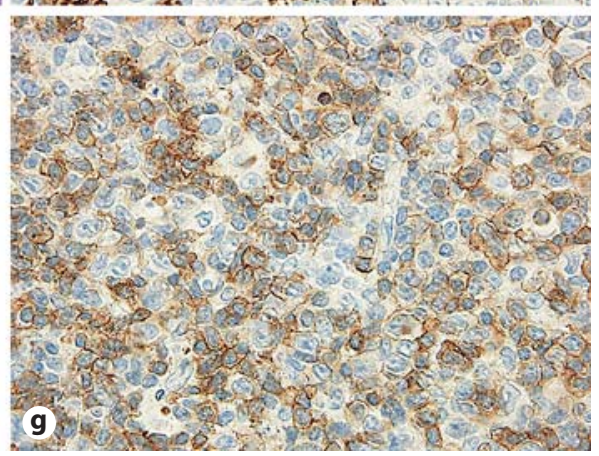

plasm (fig. 2c). Lymphoepithelial lesions were not evaluated.

Staining with CD20 and CD5 showed the mixed nature of small and medium lymphocytes and immunoblasts including cells resembling $\mathrm{H}$ cells (fig. $2 \mathrm{~d}$, e). A portion of immunoblasts were $\mathrm{CD} 30+$. There were no CD43+ B lymphocytes. Immunohistochemical studies of light chain determinants for interfollicular plasma cells, plasmacytoid cells and B immunoblasts including cells resembling $\mathrm{H}$ cells demonstrated a polyclonal pattern. Staining with a monoclonal antibody cocktail of $2 \mathrm{G} 9+\mathrm{RLB} 25$ or $1 \mathrm{~B} 12$ highlighted the meshwork of follicular dendritic cells (FDCs). Although the majority of the FDC meshwork maintained a regular arrangement, a portion of the meshwork was broken into clusters (fig. 2f).

Epstein-Barr Virus-Related Lymphoproliferative Disorders

\section{EBV Findings}

On in situ hybridization, EBER+ cells were demonstrated in the lesions in all 9 cases. The number of EBER+ cells exceeded 200 in 6 cases (No. 1, 2, 4, 5, 8 and 9). In 1 case (No. 6), approximately $50 \mathrm{EBER}+$ cells were found. In 2 cases (No. 3 and 7), only less than 10 EBER+ cells were found in the overall lymph nodes. Scattered EBER+ cells were located in the germinal centers as well as interfollicular areas in 2 cases (No. 4 and 8) (fig. 2g), whereas EBER+ cells were located only in the interfollicular area in the remaining 7 cases (No. 1-3, 5-7 and 9).

\section{Genotypic Findings}

A discrete band of amplified IgH gene was found in 3 cases (No. 1, 6 and 8) (fig. 2h), respectively. In the remaining 4 cases (No. 2, 3, 5 and 7), only germ line bands were detected. 

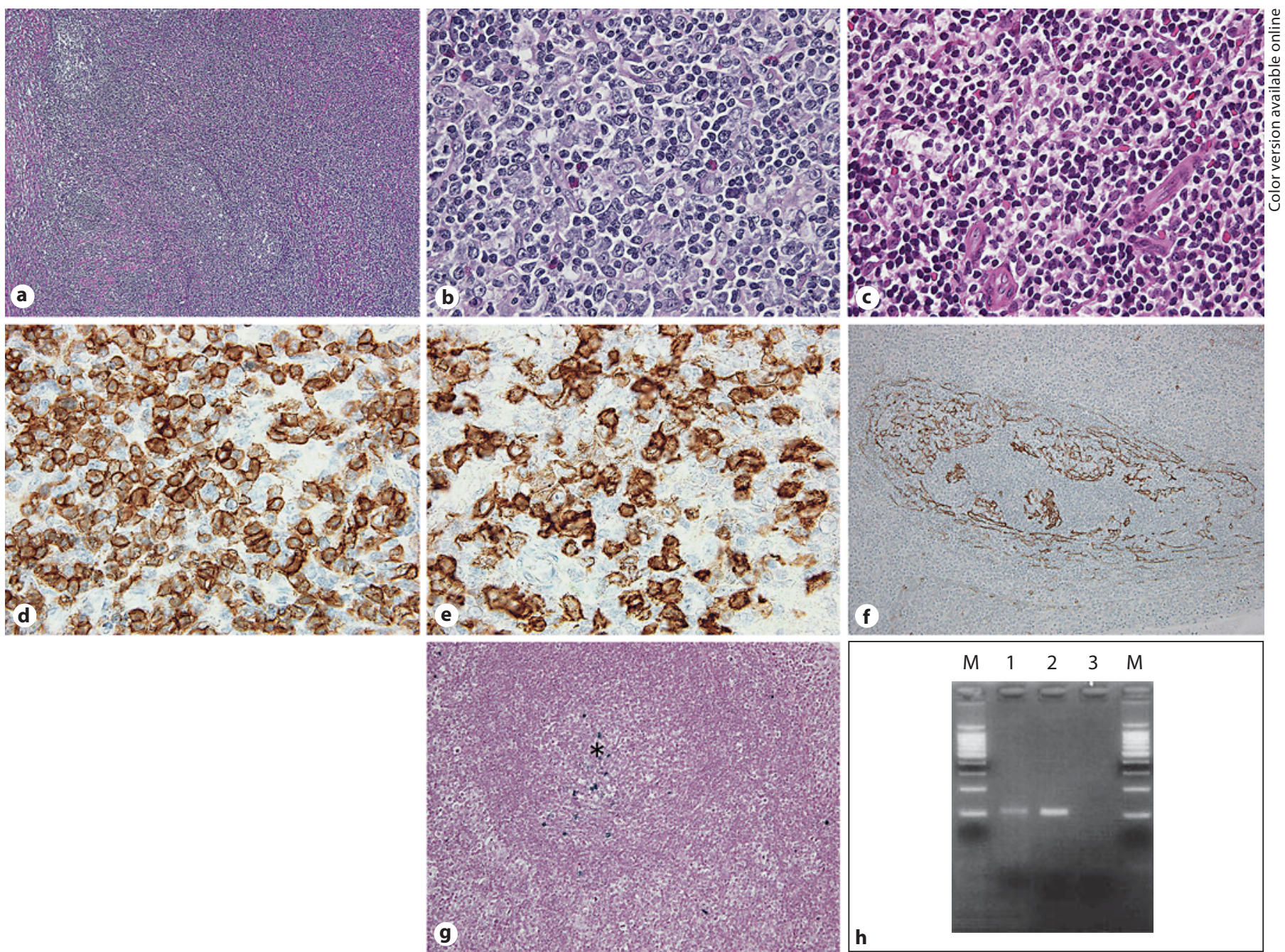

Fig. 2. a Low-power field of biopsy specimen. The lesion was characterized by diffuse interfollicular hyperplasia with small vessel proliferation and a hyperplastic germinal center with ill-defined borders (case 8$)$. HE. $\times 10$. b On high-power field, the interfollicular area contained mature plasma cells, plasmacytoid cells, immunoblasts, epithelioid histiocytes, eosinophils and small and medium-sized lymphocytes (case 8). HE. $\times 100$. c On high-power field, the small lymphoid cells usually had regular round nuclei, whereas medium-sized cells occasionally showed nuclear irregularities including angulated forms and had a moderate amount of

Evaluation of Biopsy Specimen of Case 7 Who Was Diagnosed as Having Diffuse Large B Cell Lymphoma Flow-cytometric results and PCR findings in both initial and secondary biopsy specimens demonstrated a reactive nature of B lymphocytes. Recurrent lymph node biopsy specimens showed reactive monocytoid B cell hyperplasia by reexamination. Overall, this case was considered to represent essentially reactive lymphoproliferation. clear cytoplasm (case 6). HE. $\times 100$. CD5 (d) and CD20 (e) immunostain demonstrated the mixed nature of the small to medium-sized lymphocytes and immunoblasts (case 8). HE. $\times 100$. f A cocktail of monoclonal antibody 2G9 + RLB25 immunostaining. FDC meshwork was broken into clusters (case 8). HE. $\times 25$. g Note the numerous EBV-infected lymphocytes in the germinal center $\left({ }^{*}\right)$ as well as in the interfollicular area (case 8$)$. HE. $\times 25$. h PCR analysis for clonal $\mathrm{IgH}$ rearrangement in case 8 . The lanes contain marker (M), positive control (1), case 8 (2), negative control (3) and marker (M).

\section{Discussion}

The present 9 cases demonstrated atypical clinical findings including the following: (1) all 9 cases presented with tonsillar mass; (2) 6 patients were over 30 years old; (3) absence of atypical lymphocytosis of the peripheral blood in all 9 cases; (4) presence of 'B' symptoms in only 1 case, and (5) absence of high titers of EBV antibodies in 
1 case. Moreover, clinically, IM was not suspected in any of the 9 cases. Because a clinical diagnosis of malignant lymphoma could not be excluded, these 9 patients underwent tonsillar biopsy. Histologically, three types were delineated: (1) HL-like $(\mathrm{n}=1)$; (2) TCHRLBCL-like $(\mathrm{n}=4)$, and (3) MALT-type lymphoma-like $(\mathrm{n}=4)$.

In earlier reports, the description of RS-like cells in IM generated a great deal of interest [12-14]. Consequently, the literature has tended to emphasize the differential diagnosis of IM from HL $[1,14]$. However, recent reports emphasized the differential diagnostic problems between EBV-associated LPDs and non-HL particularly diffuse large B cell lymphoma [3-9].

HL occurs predominantly in a nodal-based disease, and primary extranodal presentation is very rare $[8,15]$. When it presents in extranodal tissues, WR, particularly the palantine tonsil, is a common site. Most patients present with classical HL (frequently mixed cellularity subtype) and show a strong association with EBV $[8,15-17]$. Case 1 contained numerous $H$ cells and RS-like cells as well as large B cells. In case 1 , the majority of the $\mathrm{H}$ cells and RS-like cells were CD20+, CD30+, CD15- [15]. Moreover, large $\mathrm{B}$ cells including $\mathrm{H}$ cells contained polytypic intracytoplasmic immunoglobulins [18]. These immunophenotypic findings of case 1 were different from those of classical HL $[6,15,18]$.

Four of our 9 cases showed histopathological findings similar to those of TCHRLBCL $[19,20]$. Histomorphologically, these 4 lesions were characterized by scattered large lymphocytes observed in a background of numerous small lymphocytes $[19,20]$. The majority of the large lymphocytes showed a B cell phenotype, whereas only a minority of large lymphocytes also expressed $\mathrm{T}$ cell antigen. There were no bcl-6+ large B cells in any of the 4 lesions $[19,20]$. Moreover, there were various numbers of $\mathrm{CD} 30+$ and/or EBER+ large B cells in all 4 lesions. Overall immunohistochemical and EBV findings of 4 lesions differed from those of TCHRLBCL $[19,20]$.

Previously, using surgically resected specimens, we have indicated that MZBCL, particularly the MALT type, frequently affected the WR [21]. Four of our 7 cases showed histopathological findings similar to those of MALT-type lymphoma. Histologically, 4 lesions were characterized by a marginal zone distribution pattern of atypical lymphocytes, which is a characteristic histological finding of MALT-type lymphoma [22, 23]. Lymphoid infiltration contained medium-sized lymphocytes with irregular nuclei and a moderate amount of clear cytoplasm somewhat resembling centrocyte-like (CCL) cells, immunoblasts, plasmacytoid cells and plasma cells $[22$,
23]. Plasma cell differentiation has been noted in various degrees in MALT lymphoma, and plasma cells may occasionally obscure the CCL cells $[22,23]$. Moreover, a portion of the MALT-type lymphoma was associated with prominent epithelioid cell reaction [24]. Breakage of the FDC network seen in case 2 also suggested the follicular colonization of MALT-type lymphoma [22, 23]. However, cells resembling CCL cells were CD20+ but CD43- $[23,25]$. The polytypic nature of the B immunoblasts, plasmacytoid cells and plasma cells was demonstrated by the immunohistochemical study. Moreover, MZBCL is rarely associated with EBV [22, 23].

Immunohistochemical and flow-cytometric study demonstrated the reactive nature of the $\mathrm{B}$ cells in all 9 lesions. However, 3 (No. 1, 6 and 8) of our 7 cases examined by PCR demonstrated IgH gene rearrangement. There was no development of B cell lymphoma or recurrence of $\mathrm{B}$ cell lymphoma in any of the 3 lesions demonstrating IgH rearrangement. Moreover, 2 (No. 6 and 8) of the 3 cases showed a relatively long-term survival (48 and 61 months). As Nam-Cha et al. [26] indicated, it remains unclear whether these cases are clinically relevant, could be a sign of the prelymphomatous stage, or merely represent an exaggeration of the normal $\mathrm{B}$ cell clonal response. However, 1 case (No. 1) showed a relatively short followup period. To clarify this issue, further study is needed.

There were no abnormal serological findings for EBV in case 1. Moreover, serological examinations for EBV were not performed in 2 cases (No. 2 and 7). In WR, reactivity of lymphoid cells for EBV has been reported in lymphoid tissues of a high percentage of patients with previously asymptomatic EBV infection [27-29]. Only a few EBV+ small lymphocytes were usually detected in patients with previously asymptomatic infection [27-29], whereas numerous EBER+ large B cells were observed in 3 lesions. These 3 cases were considered to be primary EBV infection or EBV reactivation $[1,7,30]$.

When IM is not suspected clinically, microscopic findings in the tonsillar specimens can pose serious differential diagnostic problems for surgical pathologists, and may lead to a misdiagnosis of malignant lymphoma. To avoid overdiagnosis and overtreatment, we emphasize awareness of the atypical clinical presentation of EBVrelated LPDs and the need for careful attention to the clinical and laboratory findings as well as morphologic features in these cases. The present study indicated that EBV-associated LPD should be added to the differential diagnosis for MZBCL. 


\section{References}

1 Symmers WSC: Infectious mononucleosis; in Henry K, Symmers WSC (eds): Thymus, Lymph Node, Spleen and Lymphatics. Systemic Pathology, ed 3. Edinburgh, Churchill Livingstone, 1992, vol 7, pp 432-437.

$\checkmark 2$ Henle W, Henle GE, Horwiltz CA: EpsteinBarr virus specific diagnostic tests in infectious mononucleosis. Hum Pathol 1974;5: 551-565.

$\checkmark 3$ Childs CC, Parham DM, Berard CW: Infectious mononucleosis. The spectrum of morphologic changes simulating lymphoma in lymph node and tonsils. Am J Surg Pathol 1987;11:122-132.

4 Shin SS, Berry GJ, Weiss LM: Infectious mononucleosis, diagnosis by in situ hybridization in two cases with atypical features. Am J Surg Pathol 1991;15:625-631.

5 Strickler JG, Fedeli F, Horwitz CA, Copenhaver CM, Frizzera G: Infectious mononucleosis in lymphoid tissue-histopathology, in situ hybridization and differential diagnosis. Arch Pathol Lab Med 1993;117:269-278.

6 Mills SE, Gaffey MJ, Frierson HF: Tumor of the upper aerodigestive tract and ear; in Atlas of Tumor Pathology, 3rd series. Bethesda, Armed Forces Institute of Pathology, 2000, vol 26, pp 204-206.

$\checkmark 7$ Kojima M, Kashimura M, Itoh H, et al: Epstein-Barr virus related reactive lymphoproliferative disorders in middle-aged or elderly patients presenting with atypical features. A clinicopathological study of six cases. Pathol Res Pract 2007;203:587-591.

8 Chan ALC, Chan JKC: Haematolymphoid tumours; in Barnes L, Eveson JW, Reichart P, Sidransky D (eds): Pathology and Genetics of Head and Neck Tumours. Lyon, IARC Press, 2005, pp 199-205.

9 Ioachim HL, Medeiros LJ: Ioachim's Lymph Node Pathology, ed 4. Philadelphia, Lippincott, Williams \& Wilkins, 2009, pp 76-82.

$>10$ Kojima M, Kitamoto Y, Shimizu K, Matsuda $\mathrm{H}$, Masawa N: Tonsillar lesions of infectious mononucleosis resembling MALT type lymphoma. A report of two cases. Pathol Oncol Res 2008; 14:489-492.

-11 Kuze T, Nakamura N, Hashimoto Y, Abe M: Most of CD30+ anaplastic large cell lymphoma of B cell type show a somatic mutation in the IgH V region genes. Leukemia 1998;12: 753-757.
12 Salvador AH, Harrison EG Jr, Kyle RA: Lymphadenopathy due to infectious mononucleosis: its confusion with malignant lymphoma. Cancer 1971;27:1029-1040.

13 Tindle BH, Parker JW, Lukes RJ: 'ReedSternberg cells' in infectious mononucleosis? Am J Clin Pathol 1972;58:607-617.

14 Gowing NFC: Infectious mononucleosis: histopathologic aspects. Pathol Annu 1975; 10:1-20.

15 Stein H, Delsol G, Pileri SA, Weiss LM, Poppema S, Jaffe ES: Classical Hodgkin lymphoma, introduction; in Swerdlow SH, Campo E, Harris NL, Jaffe ES, Pileri SA, Stein H, Thiele J, Vardiman JW (eds): WHO Classification of Tumours of Heamatopoietic and Lymphoid Tissues, ed 4. Lyon, IARC Press, 2008, pp 326-329.

16 Kapadia SB, Roman LN, Kingma DW, Jaffe ES, Frizzera G: Hodgkin's disease of Waldeyer's ring. Clinical and histoimmunophenotypic findings and association with EpsteinBarr virus in 16 cases. Am J Surg Pathol 1995; 19:1431-1439.

17 Moghe GM, Borges AM, Soman CS, Naresh $\mathrm{KN}$ : Hodgkin's disease involving Wardeyer's ring: a study of four cases. Leuk Lymphoma 2001;41:151-156.

18 Isaacson PG, Schmid C, Pan L, Wottheer spoon AC, Wright DH: Epstein-Barr virus latent membrane antigen protein expression by Hodgkin and Reed-Sternberg-like cells in acute infectious mononucleosis. J Pathol 1992;167:267-271.

19 Achten R, Verhoef G, Vanuytesel L, De WolfPeeters C: Histiocyte-rich, T-cell-rich B-cell lymphoma: a distinct diffuse large B-cell lymphoma subtype showing characteristic morphologic and immunophenotypic features. Histopathology 2002;40:31-45.

20 De Wolf-Peeters C, Delabie J, Campo E, Jaffe ES, Delsol G: T-cell/histiocyte-rich large Bcell lymphoma; in Swerdlow SH, Campo E, Harris NL, Jaffe ES, Pileri SA, Stein H, Thiele J, Vardiman JW (eds): WHO Classification of Tumours of Heamatopoietic and Lymphoid Tissues, ed 4. Lyon, IARC Press, 2008, pp 238-239.
21 Kojima M, Nakamura N, Shimizu K, Tamaki Y, Itoh H, Nakamura S: Marginal zone B-cell lymphoma among primary B-cell lymphoma of Waldeyer's ring: histopathologic and immunohistochemical study of 16 tonsillectomy specimens. Int J Surg Pathol 2008;16: 164-170.

22 Isaacson PG, Spencer J: Malignant lymphoma of mucosa-associated lymphoid tissue. Histopathology 1987;11:445-462.

23 Isaacson PG, Chott A, Nakamura S, MüllerHermelink HK, Harris NL, Swerdlow SH: Extranodal marginal zone lymphoma of mucosa-associated lymphoid tissue (MALT lymphoma); in Swerdlow SH, Campo E, Harris NL, Jaffe ES, Pileri SA, Stein H, Thiele J, Vardiman JW (eds): WHO Classification of Tumours of Heamatopoietic and Lymphoid Tissues, ed 4. Lyon, IARC Press, 2008, pp 214-217.

24 Patsouris E, Noël H, Lennert K: Lymphoplasmacytic/lymphoplasmacytoid immunocytoma with a high content of epithelioid cells. Histologic and immunohistochemical findings. Am J Surg Pathol 1990;14:660-670.

25 Lai R, Weiss LM, Chang KL, Arber DA: Frequency of CD43 expression in non-Hodgkin lymphoma. A survey of 742 cases and further characterization of rare CD43+ follicular lymphomas. Am J Clin Pathol 1999;111:488494.

26 Nam-Cha SH, San-Millán B, Mollejo M, et al: Light-chain restricted germinal centers in reactive lymphadenitis: report of eight cases. Histopathology 2008;52:436-444.

27 Tao Q, Srivastava G, Chan AC, Chung LP, Loke SL, Ho FC: Evidence for lytic infection by Epstein-Barr virus in mucosal lymphocytes instead of nasopharyngeal epithelial cells in normal individuals. J Med Virol 1995;45:71-77.

-28 Tao Q, Srivastava G, Chan ACL, Ho FCS: Epstein-Barr-virus infected nasopharyngeal intraepithelial lymphocytes. Lancet 1995; 345:1309-1310.

29 Hudnall SD, Ge Y, Wei L, Yang NP, Wang HQ, Chen T: Distribution and phenotype of Epstein-Barr virus-infected cells in human pharyngeal tonsils. Mod Pathol 2005;18: 519-527.

-30 Shimoyama Y, Asano N, Kojima M, et al: Age-related EBV-associated B-cell lymphoproliferative disorders: diagnostic approach to a newly recognized clinicopathologic entity. Pathol Int 2009;59:835-843. 